\title{
Teacher Correction or Word Processors: Which Is a Better Option for the Improvement of EFL Students' Writing Skill?
}

\author{
Fatemeh Behjat \\ Islamic Azad University, Abadeh Branch, Abadeh, Iran \\ Email address: fb_304@yahoo.com
}

\begin{abstract}
Computers have found their way into language classrooms. It seems machines are slowly taking over from teachers all tedious working which must be done with error in language classes, all the repetitive and time-consuming jobs that make machines of teachers (Kenning, 1990). One of the ways of using computers in language classrooms is word processors to help students in writing mechanics and grammar. This study was done to see if there is any significant difference in the Iranian EFL learners' writing when they use a word processor. For this purpose, a number of 60 sophomore EFL students at Shiraz Islamic Azad University were chosen. Two topics were assigned to write two paragraphs about. It was considered as the pretest. Then, participants were divided into two groups. For treatment, the subjects practiced paragraph writing. In the first group, the teacher corrected the papers, and in the second, the students used the word processor for making corrections. Finally, another paragraph writing test was given to them. The comparison between the students' scores showed that there was a significant difference in the final performance of the two groups. Therefore, this study supports the idea that word processors improve the EFL learners' writing mechanics.
\end{abstract}

Index Terms - CALL (Computer-Assisted Language Learning), word processor, writing skill, foreign language learning, teacher-correction

\section{INTRODUCTION}

Learners are intelligent - much more intelligent, in fact than teachers think - and we often do not credit for them. Computers, on the other hand, are stupid. They do exactly what we tell them to do, no more no less. But we can use this stupidity to our own advantage in language learning process. Sudkamp (1988)

The widespread use of computers has created enormous opportunities for learners to enhance their language skills. Technology-enhanced language learning was given a huge theoretical boost when Sydney Papert (1993) and others applied the principles of Piaget (1950) to the use of computers. "Constructivism" involves the use of problem-solving during tasks rather than direct instruction by the teacher. In CALL (Computer-Assisted Language Learning), this theory implies learning by using computer tools to explore a foreign language.

According to Wikipedia, the free encyclopedia, Computer-Assisted Language Learning (CALL) is a form of computer-based learning not a method. CALL materials are, in fact, tools for learning. They are used in teaching to facilitate the language learning process. CALL is a sort of student-centered learning.

Computer-Assisted Language Learning originates from CAI (Computer-Assisted Instruction) which can be used to reinforce what has been learned in the classroom, or it can also be used as remedial to help learners with limited language proficiency. CALL's origin and development traces back to 1960's (Ferris, 2002). Since the early days CALL has developed to link technology and pedagogy.

Warschauer (1996) divided the development of CALL into three phases: behavioristic CALL, communicative CALL, and integrative CALL (multimedia and the internet). Behavioristic CALL is defined by behavioristic theories of learning of Skinner. Because repeated exposure to materials was considered to be beneficial or even essential, computers were considered ideal for this aspect of learning as the machines did not get bored or impatient with learners. Communicative CALL is based on the communicative approach in which the focus is on using a language rather than analyzing it. Integrative/explorative CALL, starting from the 1990's, tries to integrate the teaching of language skills into tasks to provide directions. CALL in this period saw the use of computers as a medium to extend education beyond the class and formal instruction.

A number of pedagogical approaches have developed in the computer age, including communicative and integrative approaches. Others include constructivism, whole language theory, and sociocultural theory although they are not exclusively theories of language learning. With constructivism, students are active participants in a task in which they construct new knowledge based on experience to incorporate new ideas into their schema of knowledge. Whole language theory postulates that language learning moves from the whole to the part, rather than teaching the sub-skills like grammar toward higher abilities like writing. Whole language insists on the opposite. Sociocultural theory states that learning is a process of becoming part of a desired community and learning that community's rules of behavior 
(Harmer, 2001). What most approaches have in common is taking the central focus from the teacher to students' experience. The computer provides the opportunity for students to be less dependent on a teacher and have more freedom to experiment on their own with natural language.

A number of studies have been done concerning how the use of CALL affects the development of language learners' four skills. Rivers (1968) states students working with computer programs in language learning don't experience the feeling of isolation and depersonalization that some expect. The computer anticipates problems and does corrections and gives comments on students' weaknesses and misunderstandings. Computers never put pressure on students and never move to further practice or work new until students request it. She then adds that some students say computers are so kind. Boswood (1999) mentions the advantages of CALL in a logical way. Generally, the use of computers inside or outside the classroom tends to make the learning job more interesting and raise their motivation. Computers adapt learning to the students, which means that the students control the pace of learning, and it helps them feel more competent in the learning process, and the use of computer technology improves self-concept and mastery over basic skills and helps them think critically and direct their own learning.

One of the basic language skills is writing which consists of some sub-skills such as spelling, grammar, and punctuation. Peter Elbow (1992) expresses the conventional understanding of writing is as a two-step process. First, you figure out the meaning; then you put it into language. He says process is not the end; it is the means to the end. Brown (2001) says that trends in the teaching of writing in a foreign language classroom have not coincided with those of the teaching of other skills. He makes a distinction between writing as a process or product. To him, there is nothing inherently wrong with attention to any of these two aspects. He introduces different types of classroom writing performance: imitative or dictation, controlled or intensive, self-writing, real writing (that is, academic, technical, and personal).He then shows the six general categories that are often the basis for the evaluation and suggestion to the students' writings. They include content, organization, discourse, syntax, vocabulary, and mechanics. According to Holmes and Kidd (1982) as all language skills and sub-skills benefit from the computer, so does the grammar and writing.

As Hanson-Smith (2001) puts it, one of the earliest computer technologies adapted by language teachers is the word processor. Through it, computers can enhance all aspects of the writing process, allowing easy revision and multiple drafts, spell-checking ( which can teach spelling by raising students' awareness levels); they allow increasingly sophisticated translation suggestions and grammatical advice are available, which may be used with caution by teachers.

Turkle (1984) cites the case of Tanya, a pupil whose writing changed drastically when she got access to a computer. From never writing anything, she grew to like writing so much as to see herself as a writer. She had beautiful ideas but she didn't know grammar well and too many spelling errors in her writing made it as an unacceptable one. The computer offered her a product that looked so neat and at the same time grammatically correct and free from spelling and punctuation errors that was unquestionably right, a feeling she had never known before using CALL. She was painfully aware of her deficits, ashamed of them, and above all, afraid of being discovered.

Studies by Jones and Fortescan (1987), Leech and Candlin (1986), and Hardisty and Windeatt (1989) reflect the fact that computers provide specific writing facilities in a foreign language. Word processing, the one outstanding successful use of the personal computers, adapts to language teaching by enabling students to compose and try out their writings.

According to Reinders (2007), there are many good reasons for using computers in writing classes: a word-processor removes the problem of handwriting; it allows the students to edit their material at great speed and facility; spellcheckers can ease the task of achieving correct spelling. By the way, a computer screen frequently allows students to see their writings objectively.

Based on what scholars state in the field, where technology is deployed to its best advantage, we should see teachers' roles become that of guide and mentor, encouraging students to take charge of their own learning, helping them to learn at their own pace.

In order to see whether computers can help foreign language learners much better than the teachers in the improvement of their writings, the following question was raised:

Q- Is there any difference between the writing performance of students who use computers and those who are directed by the teacher?

Based on this question, a null hypothesis was formed:

H0- There is no significant difference between the writing performance of those who use computers (i.e., a word processor) and those who are helped by the teacher.

\section{METHOD}

\section{A. Participants}

60 out of 150 available sophomore EFL students majoring in English translation at Islamic Azad University in Shiraz were randomly chosen as the participants of the study. They had all passed their grammar 1and 2 courses; therefore, they were assumed to have the same background in English grammar.

\section{B. Materials}


The materials used in this study were two paragraph writing tests given to the participants at the beginning and end of instruction as their pre and post test. For their treatment, while a group of subjects gave their class assignments to be corrected by the teacher, the other group used a word processor for checking spelling, pronunciation, and grammar of their writings.

\section{Procedure}

The use of computers for typing class assignments by the students in language classrooms seems quite common these days, and most of the students are familiar with Microsoft Word to do the job. In some other classes, however, there are still teachers who ask the students to hand in the hand-written form of their writing homework. In this case, the teacher should not only check the content, organization and vocabulary use in the writings, but she also has to check the students' writings for spelling, grammar, and punctuation.

A group of 60 sophomore students studying English translation at Islamic Azad University in Shiraz were chosen randomly. Then, they were divided into two groups. To make sure that the students were truly randomly chosen, or in other words, they were homogeneous, a writing test was given to them as their pre-test. The teacher assigned two topics to all students to write a paragraph for each. The papers were corrected based on Brown's (2001) model of evaluation writing. A $t$-test was applied to compare the mean of the students' raw scores.

Then, for a period of four months, the students were given a topic each week to write a paragraph on. For the first group, the students were asked to hand in the hand-written form of their assignments to the teacher. The teacher corrected the students' writings and brought them back to the students the following session. For the next group, however, the students were asked to type their assignments using Microsoft Word Office 2003, and check their writings' spelling, grammar, and punctuation before they hand them in to the teacher. Here, the teacher needed only to check the writings' organization, discourse, and content.

At the end of the treatment, again another writing test was given to the students as their post-test. The students' raw scores in the post-test were then compared by another $t$-test.

\section{RESULTS AND DISCUSSION}

To see if the students were homogeneous at the beginning of the instruction, a writing test was given to all the students. Brown's (2001) evaluation scheme was used to correct the students' writing. The students' raw scores were then collected and entered the computer. The SPSS program was run and an independent t-test was used to do the comparison between the subjects' writing scores in both groups. The results are as follows:

TABLE 1:

STUDENTS' MEAN SCORE AND STANDARD DEVIATION IN DIFFERENT GROUPS

\begin{tabular}{|l|l|l|l|l|}
\hline Variable & Number of Cases & Mean & SD & SE of Mean \\
\hline PRE1CODE 1 & 30 & 14.1167 & 2.326 & .425 \\
CODE 2 & 30 & 14.7750 & 2.397 & .438 \\
\hline
\end{tabular}

TABLE 2:

INDEPENDENT T-TEST TO COMPARE STUDENTS' WRITING RAW SCORES IN THE PRE-TEST

\begin{tabular}{|l|l|l|l|l|l|}
\hline Variances & $\mathrm{t}-\mathrm{value}$ & $\mathrm{df}$ & 2 -Tail Sig & SE of Diff & CI for Diff \\
\hline Equal & -1.08 & 58 & .285 & .610 & $(-1.879, .563)$ \\
Unequal & -1.08 & 57.95 & .285 & .610 & $(-1.879, .563)$ \\
\hline
\end{tabular}

Since the value of $\mathrm{t}(\mathrm{t}=-1.08)$ is not so different from the critical $\mathrm{t}(\mathrm{t}=.2)$, it can be concluded that the difference between the performance of subjects in the two groups was not significant, and thus the subjects were randomly chosen. The mean score of the first group who were supposed to deliver their hand-written homework to the teacher was 14.11 whereas the mean score for the second group who were to hand in their typed computer-checked assignments was 14.77 .

To answer the research question regarding the difference in the subjects' performance in the post-test of writing, another t-test was applied. The results are tabulated in the following tables:

TABLE 3:

STUDENTS' MEAN SCORE AND STANDARD DEVIATION IN THE POST-TEST

\begin{tabular}{|l|l|l|l|l|}
\hline Variable & number of Cases & Mean & SD & SE of Mean \\
\hline CODE 1 & 30 & 14.3633 & 2.345 & .428 \\
CODE 2 & 30 & 17.7500 & 1.507 & .275 \\
\hline
\end{tabular}

TABLE 4:

INDEPENDENT T-TEST FOR STUDENTS' SCORES IN THE POST TEST

\begin{tabular}{|c|c|c|c|c|c|}
\hline \multicolumn{3}{|c|}{ t-test for Equality of Means } & \multicolumn{3}{|c|}{$95 \%$} \\
\hline Variances & t-value & $\mathrm{df}$ & 2-Tail Sig & SE of Diff & CI for Diff \\
\hline $\begin{array}{l}\text { Equal } \\
\text { Unequal }\end{array}$ & $\begin{array}{l}-6.65 \\
-6.65\end{array}$ & $\begin{array}{l}58 \\
49.47\end{array}$ & $\begin{array}{l}.500 \\
.500\end{array}$ & $\begin{array}{l}.509 \\
.509\end{array}$ & $\begin{array}{l}(-4.406,-2.368) \\
(-4.410,-2.364)\end{array}$ \\
\hline
\end{tabular}


As Table 4 suggests, the value of observed $t(t=6.65)$ is much greater than the value of critical $t(t=.5)$, it can be concluded that there was a significant difference in the performance of the two groups. The students who handed in their hand-written assignments to the teacher to be checked for all aspects of writing (including grammar, spelling, punctuation, as well as content and organization could not improve their writing (mean = 14.36) as well as the second group (represented as CODE 2) who typed their assignments, checked the grammar, spelling, and punctuation of their writings by the computer and gave them to the teacher for only content and organization check $($ mean $=17.75)$.

\section{PEDAGOGICAL IMPLiCATIONS}

The results of the present study provide strong evidence that the use of computers in language classrooms improves the learners' writing skill when it is time to ask them write in the foreign language. The results seem to be very beneficial for the teachers of English as a foreign language who wish, first of all, to improve their students' writing ability, which is one of the goals of language learning, and secondly, to reduce their own tiresome burden of correcting every single aspect of students' writings (i.e., grammar, spelling, punctuation, as well as content, discourse, and organization) when computers gives a hand in checking students' writings' spelling, punctuation, and grammar. It can also guide the language methodologists who are familiar with CALL, and are aware of the positive effect of computers in teaching a foreign language. Thus, it is justifiable if we assume that the more use of CALL and technology, the better the students' achievements in foreign language classrooms.

\section{CONCLUSION}

The purpose of this study was to see if there is any difference in the performance of students' writing when the grammar, punctuation, and spelling are checked by a computer, namely, a word processor, compared to the performance of those whose hand-written assignments were checked by the teacher. The null hypothesis made was that there is no significant difference in the writing performance of both groups. The results rejected the null hypothesis and showed that this study is in line with the findings of Holmes and Kidd (1982) as well as Leech and Candlin (1986),Jones and Fortescan (1987), and Hardisty and Windeatt (1989) and others who support the use of computers in language learning, specially with regard to writing skill. If we deeply think over the issue and look at the phenomenon from a psychological perspective, we will find out how depressing and disappointening would be for the students who are learning a foreign language to see many mistakes have been marked with a red pen on their papers! But imagine, on the other hand, how encouraging it will be for the same students to find out their own mistakes, independent of the teacher, to be mentioned by the computer with no anger, frowned eyebrows, and a low mark, and corrected by themselves through challenging again and again over their texts. After all, computers seem to be more patient over the spelling, grammar, and punctuation mistakes than teachers!

\section{REFERENCES}

[1] Boswood, T. (1999). New ways of using computers in language teaching. Alexandria, VA: TESOL Quarterly.

[2] Brown, D. H. (2001). Teaching by principles: an interactive approach to language pedagogy. $2^{\text {nd }}$ ed. London: Longman.

[3] Elbow, P. (1992). "Peer sharing and peer response". In: The writer's craft (teacher's edition).Evanston, IL: McDougal, Little \& Company

[4] Ferris, D. (2002). "Teaching students to self-edit". In: Methodology in language teaching: an anthology of current practice. J.C. Richards \& W. A. Renandya (eds). Cambridge: CUP.

[5] Hansen-Smith, E. (2001). "Computer-assisted language learning". In The Cambridge guide to teaching English to speakers of other languages. R. Carter and D. Nunan (eds). Cambridge: CUP.

[6] Hardisty, D. and Windeatt, S. (1989). CALL: computer assisted language learning. Oxford: OUP.

[7] Harmer, J. (2001). The practice of English language teaching. London: Longman.

[8] Holmes, M. and Kidd, K. (1982). Computers in use: using computers in language classroom. Oxford: OUP.

[9] Jones, C. and Fortescan, J. (1987). Language, learners, and computers. TESOL Quarterly, 24 (2), pp.307-9.

[10] Kenning, T. (1990). Languages and machines. New York: Addison Westey pub.

[11] Leech, G. and Candlin, C.N. (1986). Computers in English language teaching and research. Harlow: Longman.

[12] Papert, S. (1993). The children's machine: rethinking school in the age of the computer. New York: Basic Books.

[13] Piaget, J. (1950). The psychology of intelligence. Translated from la psychologie de l' intelligence translated by M. Piercy and DE. Berlyne. London: Rutledge and Kegan Paul.

[14] Reinders, H. (2007). Big brother is helping you: supporting self-access language learning with a student monitoring system. System,35(1), pp. 93-111.

[15] Rivers, W. (1968). Teaching foreign language skills. $2^{\text {nd }}$ ed. Chicago: University of Chicago press.

[16] Sudkamp, A.T. (1988). Languages and machines. New York: Addison Westey publishing company.

[17] Turkle, D.A. (1984). An example of the use of micro-computers in foreign language learning and teaching from high school for the academically talented. TESOL Quarterly, 22(1), pp. 69-90.

[18] Warschauer M. (1996). "Computer Assisted Language Learning: an Introduction". In Fotos S. (ed.) Multimedia language teaching, Tokyo: Logos International: 3-20. 
Fatemeh Behjat is at present an ABD (All But Dissertation) in TEFL at Islamic Azad University, Shiraz Branch and a faculty member at Islamic Azad University, Abadeh branch, Iran. She also teaches English at Zand Institute of Higher Education and Islamic Azad University in Shiraz. She has also an eight-year experience teaching English at the ILI. She has so far presented papers at international conferences in Iran and abroad, published books and a couple of articles in language journals. Her main area of interest is teaching and language acquisition. 